\title{
Analysis of Financial Performance in Dairy Enterprises; The Case Study of Konya, Turkey
}

\author{
Cennet Ŏguz ${ }^{*}$, Aysun Yener²
}

Department of Agricultural Economics, Faculty of Agriculture, Selçuk University, 42250 Konya, Turkey

\section{A R T I C L E I N F O}

\section{Research Article}

Received 02 April 2018

Accepted 21 June 2018

Keywords:

Dairy enterprises

Financial performance analysis

Konya

Turkey

Economic analysis

*Corresponding Author:

E-mail: coguz@selcuk.edu.tr \begin{abstract}
A B S T R A C T
Sustainability and development of the dairy enterprises are dependent on competitiveness. Determination of the performance of the enterprises requires measurement and analyses of the financial performance of the enterprises. The ability of dairy enterprises to continue and grow is dependent on competitiveness. It requires that the financial performance of the farm enterprises be measured and analysed in order for the enterprises to be able to detect the competition power in a healthy manner. The aim of the study is to analyse the financial performance of the dairy enterprises in Konya province by determining the capital structure. Çumra, Karapınar and Ereğli districts constituted $15 \%$ of the number of bovine animals, were selected by using sampling method. The number of dairy cattle in these enterprises constituted the main frame of the population the primary data collected from 125 dairy farm enterprises with questionnaire technique through stratified sampling method with $95 \%$ confidence interval and error margin of 5\%. The capital structure of the enterprises surveyed in the research area was classified according to their functions and the average active capital of the enterprises was calculated as $845,330.85 \$ .67 .87 \%$ of the active capital is composed of land capital, $31.70 \%$ is composed of fixed enterprises capital and $0.43 \%$ is variable working capital. The economic profitability level (EP) was determined as $6.90 \%$ and the financial profitability level (FP) indicated the success of the enterprise was calculated as $7.06 \%$. The capital turnover rate, an important indicator in the success and comparison of the enterprises, is $28.22 \%$. As a result, their development and competitiveness are slow, because they do not use enough business and investment capital.
\end{abstract}

DOI: https://doi.org/10.24925/turjaf.v6i9.1148-1153.1938

\section{Introduction}

Sustainability and development of the dairy enterprises are dependent on competitive power. The ability of an enterprise to determine its competitiveness in a healthy manner requires that its financial performance be measured and analyzed. Performing decision making, planning, control, audit and management functions effectively in the enterprises makes the financial analysis inevitable. For this reason, among the most important responsibilities of business managers is the measurement and analysis of financial performance. The capital made up of all the wealth elements allocated to production is an important factor of production as well as land, labor and entrepreneur. In this aspect, there are various studies on the success of financial performance and their profitability levels (Lachnit, 2004; Schwenker, 2007; Stadler, 2004; Zell, 2008; Kauffman and Tauer, 1986).

Agricultural enterprises in Turkey are generally far away from the idea of financial performance analysis because they do not keep accounting records. However, livestock enterprises are supported by huge financial investments and it is beneficial to analyze the financial performances of the investments in this area and determine the competitiveness of the enterprise in a healthy way (Williams et al., 1987; Mc Gilliard et al., 1990; Gloy et al., 2002; Jackson-Smith et al., 2004; Mishra and Morehart 2001; Tauer and Mishra 2006; Alvarez and Arias, 2003; El-Osta and Johnson 1998; Şahin et al., 2001; Semerci et al., 2015; Alvarez et al., 2014; Aktürk et al., 2010; Parlakay, 2015; Dagistan et al., 2009; Gul et al., 2009; Oguz and Canan 2016; Oguz and Yener, 2016). Milk farming in Konya province is also very important in this respect and it constitutes $5.24 \%$ of Turkey's total number of animals and 5.48\% of milk production (Oğuz and Yener, 2017). Dairy sector is very important for the rural development and standards of living in rural area. Than measuring and analyzing 
financial performance is important in that an agricultural enterprise can examine its own situation and compare its competitiveness with other enterprises. Among the main data needed to accurately assess the financial status of an agricultural enterprise is the need to make an inventory of every kind of capital allocated for the production, which is called the inventory (balance sheet). Inventory is the identification, assessment and listing of the entity's financial assets, debts and claims at a specific period. The main data required for the assessment of the financial status of an agricultural enterprise can be summarized as total active capital, total passive capital, equity, total income, total expenses and net profit.

\section{Material and Method}

The main material of the study was the primary data obtained from the surveys conducted with the agricultural enterprises engaged in dairy farming in Konya province. Research area particularly in Konya, $25 \%$ of total population lives in rural areas and their source of income is agricultural activities (Figure 1). The main frame of the research is animal assets of dairy farming enterprises in Çumra, Karapinar and Ereğli districts, which constitute $15 \%$ of the number of animals in Konya. In this main frame, this enterprise have formed sample volume according to stratified sampling method among simple random sampling methods (Yamane, 1967). Sample size is calculated as 125 within $99 \%$ confidence interval and with $5 \%$ error margin and the enterprises in sample size are selected randomly on the basis of voluntariness.

Table 1 Distribution of Dairy Cattle Enterprises (LAU) according to Stock Count

\begin{tabular}{l|c}
\hline Enterprise Size Groups (LAU) & Sample Size (Count) \\
\hline $0-50$ & 72 \\
$51-150$ & 38 \\
$151-+$ & 15 \\
Total & 125 \\
\hline
\end{tabular}

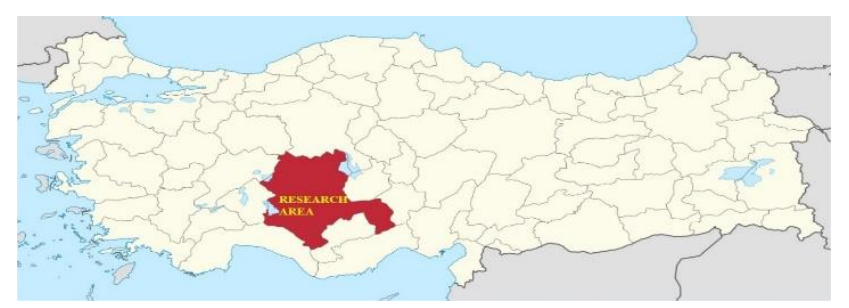

Figure 1 Research area

Capital used in enterprises requires a certain amount of expenses. Capital structures of the enterprises are examined based on the classification of the capital according to its functions (Açıl and Demirci 1984; Inan, 1994; Oguz and Yener, 2016). For this purpose, entrepreneurs' active values, which are capital elements invested in their enterprises for the purpose of production, and the passive capital that shows their sources have been put forward.

\section{Findings and Discussion}

\section{Active and Passive Capital Structure of Surveyed Enterprises}

In agricultural enterprises, capital helps net revenues increase directly. In dairy enterprises in Konya province, the capital is categorized as active and passive capital according to the capital functions. Active capital is classified as farm capital and enterprise capital. Farm capital consists of land, land improvement, building, plant, hunting and fish capital. The enterprise capital is divided into two groups as fixed enterprise capital and revolving enterprise capital. Fixed enterprise capital consists of livestock capital, tool and machine capital; and the revolving capital consists of material capital and money capital (Oğuz and Bayramoğlu, 2015). The distribution of the capital elements that constitute the active capital is important in terms of effective business management. Thus, it is important to examine the the active capital that gives the enterprise capital according to its components. In a rationally operating enterprise, the distribution of active capital is expected to be $25 \%$ for farm capital, $25 \%$ for building capital, $25 \%$ for livestock capital, $10 \%$ for tools and machine capital, $10 \%$ for material and supply capital and 5\% for money capital (Erkuş et al., 1995). However, limited cultivated agricultural land, moral loyality to the land, rapid population growth and rise in demand for non-agricultural land increase land prices. Therefore, the share of agricultural land in active capital is high. Indeed, similar results have been obtained in previous studies (Bayramoğlu, 2003; Altıntaş and Akçay, 2007; Tatlıdil et al. 2009; Semerci et al, 2014; OguzandYener, 2016).

Another capital element that is calculated more than expected amount in the field of research is the tools and machine capital. In the enterprises surveyed, milking unit, cooling tank, feed mixer, tractor and other tools and machines used in vegetative production constituted this capital group. The following chart shows the active capital of dairy enterprises (Table 1). $\$ 845,330.85$ of active capital has been identified per enterprise. $67.87 \%$ of this is the farm capital and $32.13 \%$ is the enterprise capital. As the enterprise increases, active capital per enterprise increases. As can be seen in the table, the share of the farm capital in the active capital is much more than the share that should be in a normal enterprise. Besides, the rates of plant, land improvement, material and money capital are very low. This formation of active capital is considered as a situation that affects business success negatively (Erkuş, 1979). 67.87\% of the active capital in the enterprises surveyed is farm capital, $31.70 \%$ is fixed enterprise capital and $0.43 \%$ is the revolving enterprise capital. The largest share of active capital is obtained from land $(46.84 \%)$. This is followed by animal capital (26.27\%), building capital $(18.34 \%)$ and tool and machine capital $(5.43 \%)$.

In the enterprises surveyed, passive capital is composed of foreign and equity capital used in enterprises. The land values held in the lease on the active capital of the enterprises surveyed are also included as debts. 
Table 2 Distribution (\$) and ratios (\%)of active capital in enterprises surveyed

\begin{tabular}{|c|c|c|c|c|c|c|c|c|c|}
\hline \multirow{3}{*}{\multicolumn{2}{|c|}{ Capital groups }} & \multicolumn{8}{|c|}{ Enterprise Groups (Number) } \\
\hline & & \multicolumn{2}{|c|}{$0-50$} & \multicolumn{2}{|c|}{$51-150$} & \multicolumn{2}{|l|}{$151-+$} & \multicolumn{2}{|c|}{ Enterprise averages } \\
\hline & & $\$$ & $\%$ & $\$$ & $\%$ & $\$$ & $\%$ & $\$$ & $\%$ \\
\hline \multirow{5}{*}{$\begin{array}{l}\text { Farms } \\
\text { capital }\end{array}$} & Land & $206,051.94$ & 71.70 & $494,287.44$ & 67.57 & $1,058,098.59$ & 68.32 & $395,921.13$ & 69.00 \\
\hline & LIC & $4,029.73$ & 1.40 & $15,664.38$ & 2.14 & $27,089.20$ & 1.75 & $10,333.80$ & 1.80 \\
\hline & Building & $72,079.91$ & 25.08 & $206,871.76$ & 28.28 & $422,077.46$ & 27.25 & $155,056.34$ & 27.02 \\
\hline & Plant & $5,212.86$ & 1.81 & $14,730.82$ & 2.01 & $41,414.32$ & 2.67 & $12,450.49$ & 2.17 \\
\hline & Total & $287,374.44$ & 75.93 & $731,554.39$ & 67.87 & $1,548,679.58$ & 62.02 & $573,761.76$ & 67.87 \\
\hline \multirow{3}{*}{$\begin{array}{l}\text { Fixed } \\
\text { enterprises } \\
\text { capital }\end{array}$} & Livestock & $70,070.42$ & 78.67 & $270,397.52$ & 78.93 & $829,407.28$ & 88.45 & $222,090.28$ & 82.88 \\
\hline & $\mathrm{TM}$ & $18,994.28$ & 21.33 & $72,161,32$ & 21.07 & $108,252.93$ & 11.55 & $45,868.10$ & 17.12 \\
\hline & Total & $89,064.70$ & 23.53 & $342,558.84$ & 31.78 & $937,660.21$ & 37.55 & $267,958.38$ & 31.70 \\
\hline \multirow{3}{*}{$\begin{array}{l}\text { Revolving } \\
\text { farm } \\
\text { capital }\end{array}$} & MSC & 709.12 & 35.19 & $2,038,55$ & 53.70 & $6,807.51$ & 63.04 & $1,845.07$ & 51.10 \\
\hline & $\mathrm{MC}$ & $1,306.4$ & 64.81 & $1,757.79$ & 46.30 & $3,990.61$ & 36,96 & $1,765.63$ & 48.90 \\
\hline & Total & $2,015.36$ & 0.53 & $3,796.33$ & 0.35 & $10,798.12$ & 0.43 & $3,610.70$ & 0.43 \\
\hline \multirow{2}{*}{\multicolumn{2}{|c|}{$\begin{array}{l}\text { Total farms capital } \\
\text { Total active capital }\end{array}$}} & $91,080.06$ & 24.07 & $346,355.17$ & 32.13 & $948,458.33$ & 37.98 & $271,569.08$ & 32.13 \\
\hline & & $378,454.50$ & 100 & $1,077,909.56$ & 100 & $2,497,137.91$ & 100 & $845,330.85$ & 100 \\
\hline
\end{tabular}

LIC: Land improve capital, TM: Tools machines, MSC: Materials and supplies capital, MC: Money capital, Resources; Calculated by the authors according to research results.

Table 3 Distribution and ratios (\%) of passive capital (\$)in the surveyed enterprises

\begin{tabular}{|c|c|c|c|c|c|c|c|c|}
\hline & \multicolumn{8}{|c|}{ Enterprise groups (Number) } \\
\hline & \multicolumn{2}{|l|}{$0-50$} & \multicolumn{2}{|c|}{$51-150$} & \multicolumn{2}{|c|}{$151-+$} & \multicolumn{2}{|c|}{ Enterprise averages } \\
\hline & $\$$ & $\%$ & $\$$ & $\%$ & $\$$ & $\%$ & $\$$ & $\%$ \\
\hline Short-term debts & $1,222.61$ & 0.32 & $1,113.32$ & 0.10 & 938.97 & 0.04 & $1,155.35$ & 0.14 \\
\hline Long-term debt & $14,558.88$ & 3.85 & $11,695.70$ & 1.09 & $9,361.50$ & 0.37 & $13,064.79$ & 1.55 \\
\hline Total & $15,781.49$ & 4.17 & $12,809.03$ & 1.19 & $10,300.47$ & 0.41 & $14,220.14$ & 1.68 \\
\hline Landed debts & $16,336.56$ & 4.32 & $21,599.33$ & 2.00 & $35,915.49$ & 1.44 & $20,285.92$ & 2.40 \\
\hline Total foreign capital & $32,118.06$ & 8.49 & $34,408.36$ & 3.19 & $46,215.96$ & 1,85 & $34,506.06$ & 4.08 \\
\hline Equity & $346,336.44$ & 91.51 & $1,043,501.20$ & 96.81 & $2,450.921 .95$ & 98.15 & $810,824.79$ & 95.92 \\
\hline Total passive capital & $378,454.50$ & 100 & $1,077,909.56$ & 100 & $2,497,137.91$ & 100 & $845,330.85$ & 100 \\
\hline
\end{tabular}

Table 4 Net Profit $(\$)$

\begin{tabular}{l|cccc}
\hline & \multicolumn{4}{|c}{ Enterprise Groups (Number) } \\
\cline { 2 - 5 } & $0-50$ & $51-150$ & $151-+$ & Enterprise average \\
\cline { 2 - 5 } & $\$$ & $\$$ & $\$$ & $\$$ \\
\hline Gross product value & $85,459.89$ & $290,522.30$ & $841,720.41$ & $238,550.13$ \\
Production costs & $92,934.46$ & $279,626.54$ & $699,335.53$ & $222,456.98$ \\
Net profit & $-7,474.57$ & $10,895.76$ & $142,384.88$ & $16,093.15$ \\
\hline
\end{tabular}

Table 5 The Capital Turnover Rate (\%)

\begin{tabular}{l|cccc}
\hline & \multicolumn{4}{|c}{ Enterprise Groups (Number) } \\
\cline { 2 - 5 } & $0-50$ & $51-150$ & $151-+$ & Enterprise Averages \\
\hline Short-term debts & $1,222.61$ & $1,113.32$ & 938.97 & $1,155.35$ \\
Revolving enterprises capital & $2,015.36$ & $3,796.33$ & $10,798.12$ & $3,610.70$ \\
Gross production value & $85,459.89$ & $290,522.30$ & $841,720.41$ & $238,550.13$ \\
Total farm capital & $378,454.50$ & $1,077,909.56$ & $2,497,137.91$ & $845,330.85$ \\
Current rate & 1.65 & 3.41 & 11.50 & 3.13 \\
Capital turnover rate & 22.58 & 26.95 & 33.71 & 28.22 \\
\hline
\end{tabular}

Table 6 The Financial and Economic Profitability

\begin{tabular}{l|cccc}
\hline & \multicolumn{4}{|c}{ Enterprise Groups (Number) } \\
\cline { 2 - 5 } & $0-50$ & $51-150$ & $151-+$ & Enterprise Average \\
\hline Net profit & $-7,474,57$ & $10,895.76$ & $142,384.88$ & $16,093.15$ \\
Equity rant & $17,660,20$ & $52,870.76$ & $124,032.86$ & $41,128.93$ \\
Equity & $346,336,44$ & $1,043,501.20$ & $2,450,921.95$ & $810,824.79$ \\
Aktive capital & $378,454,50$ & $1,077,909.56$ & $2,497,137.91$ & $845,330.85$ \\
Pure product & $11,448,15$ & $64,791.24$ & $267,241.77$ & $58,359.69$ \\
Financial profitability (FP) & 2.94 & 6.11 & 10.87 & 7.06 \\
Economic profitability (EP) & 3.02 & 6.01 & 10.70 & 6.90 \\
\hline
\end{tabular}


It has been determined that the enterprises surveyed have an average of $\$ 14,220.14$ debts per business. Of these, $59.78 \%$ are animal production loans, $12.75 \%$ are private consumption loans, $12.37 \%$ are tool-machine loans, $11.04 \%$ are vegetative production loans and $4.06 \%$ are personal debts.

In the surveyed enterprises, of the debts per enterprise $58.79 \%$ are landed debts, $37.86 \%$ are long-term debts and $3.35 \%$ are short-term debts. The landed debts consist of the amount paid to the landowner for the leased land.

As can be seen in the table, the average passive capital per enterprise is $845,330.85 \$$. Passive capital differs according to enterprise groups. It has been determined as $\$ 378,454.50$ for enterprises with 0-50 animals, $\$ 1,077,909.56$ for enterprises with 51-150 animals, and $\$ 2,497,137.91$ for those with more than 150 animals.

$95.92 \%$ of the passive capital $(\$ 845,330.85)$ constitutes equity capital and $4.08 \%$ constitutes foreign capital. Therefore, equity refers to the financial share of enterprise owners in the enterprise, or the amount of risk they have on the enterprise (Akgüç, 1995).

\section{Net Profit in The Surveyed Enterprises}

Net profit is calculated by subtracting production costs from gross revenue. This is the basic indicator that measures the profitability of the business activity. The net profit for agricultural family enterprise shows the amount of resources that the family can use to meet expenses such as living expenses, taxes and capital investments. It is natural that the profit should be positive in order to talk about the improvement of the financial condition of the enterprise. If the profit is greater than zero, the revenue from the enterprise activity can be used for investment and growth purposes.

Net profit per enterprise was found by subtracting production costs from gross revenue. Net profit per enterprise was determined as 16,093.15.

\section{Financial Performance Analysis of Dairy Farming} Enterprises

To measure the financial performance of an enterprise, it is necessary to find performance data and to calculate reference (standard) values. As reference values, often ratios are used rather than absolute financial indicators.

Ratios are indicators that establish a relative relationship between two absolute performance indicators and compare one financial size to another. The advantage of relative values is that they destroy the diverting influence of the size of the enterprise on the indicator. Compared to the absolute indicators, these ratios make it possible to make more meaningful and direct comparisons between different size enterprises and thus to compare the financial performances of different enterprises in a more healthy way. The main ratios used to measure financial performance are examined in four main categories: liquidity, activity (efficiency), debt payability (leverage) and profitability.

\section{Liquidity Ratios}

Liquidity ratios are, in essence, the rates used to measure the extent to which an enterprise can meet its short-term debts and to determine whether the enterprise capital is sufficient. Here, the current ratio, which is one of the most widely used ratios in financial performance analysis, is obtained by dividing liquid assets into short term debts.

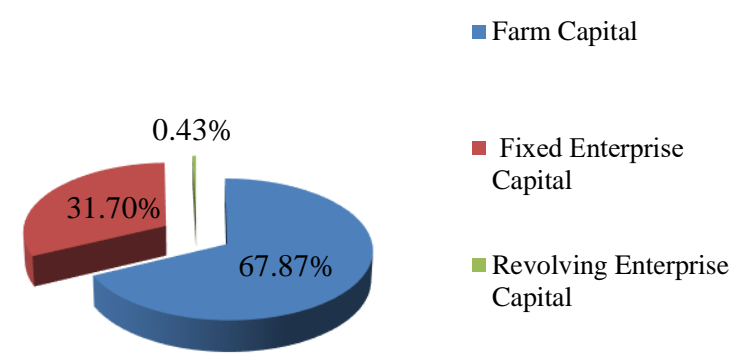

Figure 1 Proportional Distribution of Active Capital in the Enterprises Surveyed (\%)

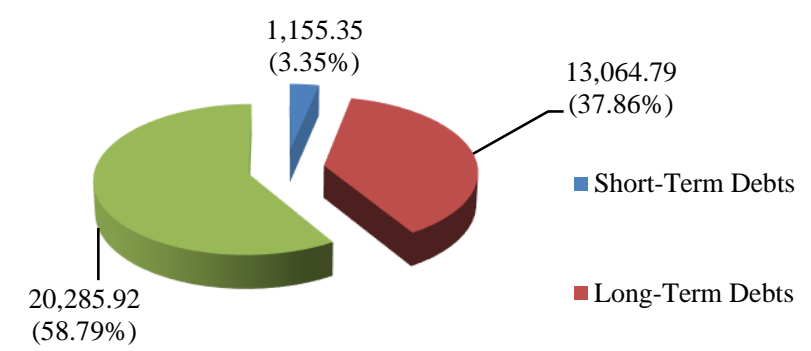

Landed Debts

Figure 2 Proportional Distribution of Foreign Capital in the Enterprises Surveyed (\%)

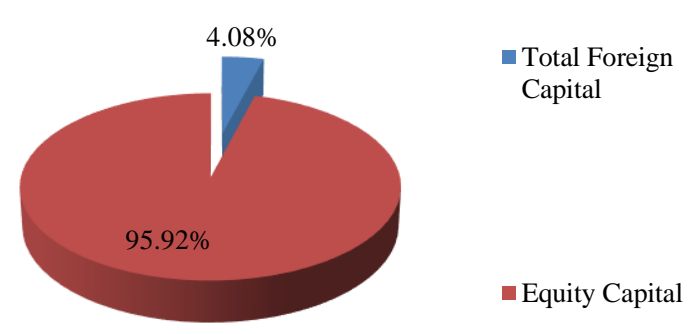

Figure 3 Proportional Distribution of Passive Capital (\%) 
It was found to be 3.13 in the surveyed enterprises. It shows the capacity of the enterprise to pay short term debts. If the current ratio exceeds one, it generally shows that they can pay their short-term debts on time. The capital turnover rate is calculated within activity (efficiency) ratios. It is calculated by dividing the gross production value by the total enterprise capital. It demonstrates how effectively the enterprise assets can produce output. The higher the rate, the better. The capital turnover rate of dairy farming enterprises in the research area is $28.22 \%$ in the average of the enterprises.

Debt payability ratio is calculated by dividing total debts into the active capital. It demonstrates the mobility of the enterprise and how much of the financial debt the enterprise can pay if all of the assets are sold. In other words, it is a rate that indicates how much of its assets an enterprise owes to its lenders or institutions. This rate was calculated as $4 \%$ in the research area. Profitability analyzes are calculated from financial and economic direction in dairy farming enterprises and the average financial profitability which shows the success of the enterprise is calculated as $7.06 \%$ and the economic profitability which shows the success of the enterprise is $6.90 \%$. The financial and economic profitability of the enterprises surveyed is given in table 5. Financial profitability (FP) measures the profitability of the equity capital owned by the enterprise and the economic profitability(EP) measures the profitability of the enterprise.

\section{Conclusion}

It can be said that dairy farming enterprises in Konya have managed the investment capital well. However, small enterprises are less able to pay their debts than large enterprises, and their financial (2.94) and economic (3.02) profitability is also low. Small enterprises are less likely to compete with larger enterprises. This is because the mobility of large enterprises is higher than that of small enterprises and their liquidity of being able to immediately close its debts in the case of the liquidation is higher (4\%). Although the financial and economic liquidity of the enterprises is high in the research area, the share of own capital is $95.92 \%$, the share of foreign capital is $4.08 \%$, and the enterprises are hesitant to take risks. The fact that the risks and uncertainties in agricultural enterprises are already so high, input costs in animal husbandry enterprises are high and the market is unstable are considered to be a disadvantage and large enterprises can not compete in the market. As a result, operators need to better manage capital. It is necessary to evaluate the management and operational results as much as the management plans.

\section{Acknowledgement}

This study was supported as a whole project by the Selcuk University, Scientific Research Fund (BAP). Project No: 15401020.

This article was presented at the congress about "The Eurasion Agriculture and Natural Sciences Congress in Kyrgizystan 20-23 September 2017, but not published.

\section{References}

Açıl AF, Demirci R. 1984. Tarım Ekonomisi Dersleri, Ankara Üniversitesi Ziraat Fakültesi Yayınları No:880, Ankara.

Akgüç Ö, 1995. Mali Tablolar Analizi, 9. Bask1, İstanbul: Muhasebe Enstitüsü Yayını.

Aktürk D, Bayramoğlu Z, Savran F, Tatlidil FF. 2011.The Factors Affecting Milk Production and Milk Production Cost: Çanakkale Case - Biga. Journal of the Kafkas University Faculty of Veterinary Medicine, v. 16, n. 2, p. 329-335, 2010.

Altıntaş G, Akçay Y. 2007. Tokat ili Erbaa ovasında tarım işletmelerinin ekonomik analizi ve işletmelerin başarısını etkileyen faktörlerin ortaya konulması. Gaziosmanpaşa Üniversitesi Ziraat Fakültesi Dergisi, 24(2): 33-42.

Alvarez A, Arias C. 2003. Diseconomies of size with fixed managerial ability. American Journal of Agricultural Economics, 85(1), 134-142.

Alvarez S, Rufino MC, Vayssières J, Salgado P, Tittonell P, Tillard E, Bocquier F. 2014. Whole-farm nitrogen cycling and intensification of crop-livestock systems in the highlands of Madagascar: an application of network analysis. Agricultural systems, 126: 25-37.

Bayramoğlu Z. 2003. Konya ilinde süt sığırcılığ1 projesi (100x2) kapsamında yer alan işletmelerin ekonomik analizi. Selçuk Üniversitesi, Fen Bilimleri Enstitüsü, Yüksek Lisans Tezi, Konya.

Dagistan E, Koc B, Gul M, Parlakay O, Akpinar MG. 2009. Identifying technical efficiency of dairy cattle management in rural areas through a non-parametric method: a case study for the East Mediterranean in Turkey. Journal of Animal and Veterinary Advances, 8(5): 863-867.

El-Osta HS, Johnson JD. 1998. "Determinants of Financial Performance of Commercial Dairy Farms." Technical Bulletin No. 1859, USDA/ERS, Washington, DC.OpenURL query | Google Scholar

Erkuş A. 1979. Ankara İli Yeni Mahalle İlçesinde Kontrollü Kredi Uygulaması Yapılan Tarım İşletmelerinin Planlanması Üzerine Bir Araştırma. Ankara Üniversitesi, Ziraat Fakültesi Yayınları, No:709, Bilimsel Araştırma Ve İncelemeler: 415, Ankara.

Erkuş A, Bülbül M, Kral T, Açıl F, Demirci R. 1995. Tarım Ekonomisi. ISBN 975-7185-01-9, Ankara. İnan, İ. H. (1994). Tarım Ekonomisi. Trakya Üniversitesi Tekirdağ Ziraat Fakültesi, Tekirdağ.

Gloy BA, Hyde J, LaDue EL. 2002. Dairy farm management and long-term farm financial performance. Agricultural and Resource Economics Review, 31(2): 233-247.

Gul M, Koc B, Dagistan E, Akpinar MG, Parlakay O. 2009. Determination of technical efficiency in cotton growing farms in Turkey: A case study of Cukurova region. African journal of Agricultural research, 4(10): 944-949.

İnan İH. 1994. Tarım Ekonomisi Kitab1, Hasat Yayıncılık, III. Bask1, Tekirdağ, $p$.

Jackson-Smith D, Trechter D, Splett N. 2004. The contribution of financial management training and knowledge to dairy farm financial performance. Review of agricultural economics, 26(1): 132-147.

Kauffman JB, Tauer LW. 1986. Successful dairy farm management strategies identified by stochastic dominance analysis of farm records. Northeast. J. Agric. Res. Econ. v, 15, p. $168-177$.

Lachnit L. 2004. Die Bilanzanalyse, Wiesbaden, Gabler Verlag. Mc Gilliard ML, Conklin VJ, James RE, Kohl DM, Benson G A. 1990. Variation in herd financial and production variables over time. Journal of dairy science, 73(6): 15251532.

Mishra AK, Morehart MJ. 2001. Factors affecting returns to labour management on U.S. dairy farms. Agric. Finance Rev. v. 61, p. 123-140. 
Oguz C, Canan S. 2016. Factors affecting milk production in dairy farming enterprises and effectiveness analysis: a case study in Konya Province of Turkey. Custos e @gronegócio on line - v. 12, n. 3 - Jul/Sep - 2016. ISSN 1808-2882.

Oguz C, Bayramoğlu Z. 2015. Tarım Ekonomisi Kitabı. Atlas Akademi 2. Basım. ISBN:978-605-63373-3-8. Konya.

Oguz C, Yener A. 2016. Economic Analysis of Dairy Cattle Enterprises: The Case Of Konya Province. Europ. Countrys. $\cdot 2 \cdot 2017 \cdot$ p. 263-273, DOI: 10.1515/euco-2017-0016.

Oguz C, Yener A. 2017. Konya İli Süt İşletmelerinin Ekonomik Faaliyet Sonuçları ve Yenilikleri Benimseme Düzeyleri, Selçuk Üniversitesi Bilimsel Araştırma Projeleri Proje No: 15401020, Konya.

Parlakay O, Semerci A, Çelik AD. 2015. Estimating technical efficiency of dairy farms in Turkey: a case study of hatay Province. Custos e @ gronegocio online.v. 11, n. 3, p. 106115, 2015.

Semerci A, Parlakay O, Çelik A. 2014. Gross margin analysis in dairy cattle: a case study of Hatay Province, Turkey. Custos e @ gronegocio online. V. 10, n. 4, p. 154-170, 2014.

Semerci A, Parlakay O, Duran Ç. 2015. Süt Sığırcılığı Yapan İşletmelerin Ekonomik Analizi: Hatay İli örneği, Tekirdağ Faculty of Agriculture Journal, v. 12, n 3, p. 8-17.
Schwenker B, Spremann K. 2007. Unternehmerisches Denken Zwischen Strategie und Finanzen, Hamburg, Springer Verlag.

Stadler W. 2004. Die Neue Unternehmens Finanzierung, Frnakfurt, Redline Verlag.

Şahin K, Gül A, Koç B, Dağıstan E. 2001. Adana ilinde entansif süt sığırcılığ 1 üretim ekonomisi. Yüzüncü Yıl Üniversitesi Tarım Bilimleri Dergisi, 11(2): 19-28.

Tauer LW, Mishra AK. 2006. Can the small dairy farm remain competitive in U.S. agriculture?. Food Policy. V. 31, p. 458468.

Tatlidil FF, Boz İ, Tatlidil H. 2009. Farmers' perception of sustainable agriculture and its determinants: a case study in Kahramanmaras proves of Turkey. Environ Dev. Sustain, v. 11, p. 1091-1106, 2009.

Williams CB, Oltenacu PA, Bratton CA, Milligan RA. 1987. Effect of business and dairy herd management practices on the variable cost of producing milk. J. Dairy Sci. v. 70, p. $1701-1709$.

Yamane T. 1967. "Elementary Sampling Theory". Prentice-Hall Inc. Englewood Cliffs, New Jersey.

Zell M. 2008. Kostenund Performance Managementund Informations technologie.Kosten-und Performance Management: Grundlagen Instrumente Fallstudie, 203-210. 